\section{JURNAL ABDIMAS

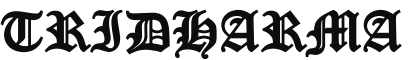 AtA}

P-ISSN 2615-6849, E-ISSN 2716-070X

Jurnal ABDIMAS Vol. 2,No.3, Agustus 2021,Hal(80-85)

@Prodi Manajemen Fakultas Ekonomi Universitas Pamulang

Email: abdimasjurnal.unpam@ gmail.com Telp: (021) 741-2566

\title{
PEMBUATAN TEH SEREH DALAM MEMANFAATKAN WAKTU LUANGMENAMBAH PENGHASILAN IBU IBU MAJELIS TAKLIM BINTARO
}

\author{
Santi Octavianti, Rissa Hanny, \\ Abdul Rahman Safiih, Cornelia Dumarya Manik, Arif Surahman \\ Dosen Dan Mahasiswa Prodi Manajemen Fakultas Ekonomi \\ Universitas Pamulang
}

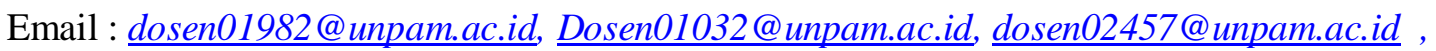
dosen00720@unpam.ac.id, dosen01176@unpam.ac.id
\end{abstract}

\begin{abstract}
ABSTRAK
Masyarakat Indonesia dan masyarakat dunia saat ini tengah disibukkan dengan sebuah permasalahan bersama, yaitu pandemi virus korona. Demi memotong mata rantai penyebaran virus covid-19, pemerintah memberlakukan berbagai kebijakan seperti, sosial distancing dan physical distancing, serta yang terbaru yaitu, Pembatasan Sosial Berskala Besar (PSBB). Tentunya menjalankan setiap aktivitas saat ini memiliki tantangan tersendiri terutama pemenuhan kebutuhan yang wajib dipenuhi, seperti sandang, pangan dan papan. Dalam masyarakat, kaum perempuan biasanya menjadi pihak yang tidak diuntungkan, kebanyakan dari mereka menggantungkan hidup mereka pada kaum lelaki sebagai pemberi nafkah. Oleh Karena itu perlu adanya pemberdayaan perempuan kususnya dalam bidang pelatihan-pelatihan membuat suatu produk sehingga ibu ibu memiliki skill dalam hal ini ibu-ibu jama'ah pengajian di RT 004 RW 005 Bintaro Pesanggrahan Jakarta Selatan sangat antusias dalam mengikuti pelatihan salah satunya pelatihan pembuataan teh yang terbuat dari sereh jika hal ini sudah dimengerti maka akan bermanfaat untuk membuka usaha mandiri serta meningkatkan taraf hidup sehingga memiliki pengahasilan sendiri. Dengan adanya pelatihan tersebut maka akan memberikan solusi yang tepat untuk mengatasi permasalahan hidup saat ini khususnya kaum ibu ibu yang ingin memiliki penghasilan sendiri di samping juga memberikan mereka pengetahuan berwirausaha yang mempunyai etika bisnis, menangani keluhan serta cara memasarkan produk yang ingin mereka jual.
\end{abstract}

\section{Kata Kunci : pandemi virus korona, pemberdayaan perempuan, wirausaha}

\begin{abstract}
Indonesian people and the world community are currently busy with a common problem, namely the corona virus pandemic. In order to cut the chain of the spread of the COVID-19 virus, the government has implemented various policies, such as social distancing and physical distancing, and most recently, Large-Scale Social Restrictions (PSBB). Of course, carrying out every activity today has its own challenges, especially meeting the needs that must be met, such as clothing, food and shelter. In society, women are usually the disadvantaged, most of them depend on men for their livelihoods as providers. Therefore, it is necessary to empower women, especially in the field of training to make a product so that mothers have skills, in this case the women of the recitation congregation in RT004 RW 005 Bintaro Pesanggrahan, South Jakarta, are very enthusiastic in participating in training, one of which is tea making training. made from lemongrass, if this is understood, it will be useful to open an independent business and improve the standard of living so that they have their own income. With this training, it will provide the right solution to overcome current life problems, especially mothers who want to have their own income while also providing them with entrepreneurial knowledge that has business ethics, handling complaints and how to market the products they want to sell.
\end{abstract}

Keywords: corona virus pandemic, women's empowerment, entrepreneurship 


\section{JURNAL ABDIMAS

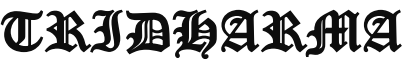 AtA}

\section{P-ISSN 2615-6849, E-ISSN 2716-070X}

Jurnal ABDIMAS Vol. 2,No.3, Agustus 2021,Hal(80-85)

@Prodi Manajemen Fakultas Ekonomi Universitas Pamulang

Email: abdimasjurnal.unpam@ gmail.com Telp: (021) 741-2566

\section{PENDAHULUAN}

Masyarakat Indonesia dan masyarakat dunia saat ini tengah disibukkan dengan sebuah permasalahan bersama, yaitu pandemi virus korona. Laju kecepatan virus Korona bahkan belum bisa diprediksi sampai kapan akan mengalami penurunan. Jika menilai dari data yang dimiliki pemerintah saat ini, justru angka penyebaran virus tersebut terus beranjak naik.

Demi memotong mata rantai penyebaran virus covid-19, pemerintah memberlakukan berbagai kebijakan seperti, sosial distancing dan physical distancing, serta yang terbaru yaitu, Pembatasan Sosial Berskala Besar (PSBB). Pemerintah DKI melalui Keputusan Gubernur daerah Khusus Jakarta Nomor 57 Tahun 2021 tentang perpanjangan pemberlakuan jangka waktu dan pembatasan aktivitas luar rumah pembatasan sosial berskala besar

Tentunya menjalankan setiap aktivitas dirumah memiliki tantangan tersendiri terutama pemenuhan kebutuhan yang wajib dipenuhi, seperti sandang, pangan dan papan. Lalu bagaimana dengan mereka yang tidak seberuntung dalam hal pendapatan, mereka harus memutar otak demi memenuhi kebutuhan untuk keberlangsungan hidup keluarganya

Dalam masyarakat, kaum perempuan biasanya menjadi pihak yang tidak diuntungkan, kebanyakan dari mereka menggantungkan hidup mereka pada kaumlelaki sebagai pemberi nafkah. Apakah hal tersebut salah? Mungkin tidak, Tetapi mungkin juga benar. Sering kita menyaksikan atau mendengar, perempuan-perempuan yang kehilangan sandaran hidup dan lalu hidup terluntalunta dengan anak-anaknya. Suatu hal yang miris yang masih terjadi di masyarakat kita. Pertanyaannya kemudian, apa yang bisa kita lakukan? Perempuan yang memiliki pengetahuan dan keterampilan cenderung lebih mandiri, kuat, dan lebih berhasil dalam menjalankan peran dan fungsinya dalam keluarga, masyarakat, dan bahkan dalam perkembangan sebuah bangsa (Khayati 19:2008). Pemberdayaan perempuan kemudian menjadi sebuah investasi jangka panjang yang menguntungkan bagi semua orang terlebih bagi kaum perempuan dalam hal ini ibu-ibu yang menginginkan kemandirian dalam hal ekonomi.

Pelatihan terkait dengan keterampilan dan kemampuan saat ini diperlukan untuk bisa melakukan pekerjaan. Menurut Amin Widjaja (251: 2012) program pelatihandiarahkan untuk mempertahankan dan memperbaiki performa pekerjaan para karyawan dalam sebuah organisasi. Menurut wibowo (370:2014), pada dasarnya pelatihan diperlukan karena adanya kesenjangan antara keterampilan pekerja sekarang dengan keterampilan yang dibutuhkan untuk menempati posisi baru. Dari beberapa pendapat di atas, dapat disimpulkan bahwa pelatihan merupakan kegiatan yang menitik-beratkan pada peningkatan keterampilan dan kemampuan untuk suatu pekerjaan.

Jumlah ibu-ibu jama'ah pengajian pada umumnya jauh lebih banyak dari jumlah laki-laki, serta mereka lebih aktif dalam mengikuti pengajian rutin yang diasuh oleh para ustadz, sehingga dapat dikatakan kegiatan pembinaan serta bimbingan agama ibu ibu jalan mawar 3 RT 004 RW 005 Bintaro Pesanggrahan Jakarta Selatan sudah berjalan lancar dan aktif. Meskipun demikian, hal itu belum berdampak signifikan bagi peningkatan keterampilan dan kemampuan ibu-ibu dalam hal memanfaatkan waktunya untuk menambah penghasilan. Tentu saja ini terkait erat dengan peran aktif ibu-ibu tersebut yang berada pada majelis ta'lim. Melihat kemauan dan keinginan para ibu ibu majelis ta'lim untuk meningkatkan taraf hidupnya serta keinginan untuk memiliki penghasilan sendiri maka perlu dilakukan berbagai perubahan yang bertujuan meningkatkan mutu sumber daya manusia ibu ibu majelis ta' lim.

Sejalan dengan peranan majelis ta'lim sebagai media penyampaian gagasan yang bermanfaat bagi 


\section{JURNAL ABDIMAS

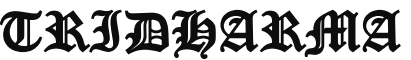

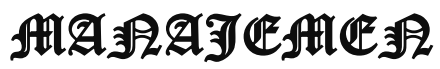

P-ISSN 2615-6849, E-ISSN 2716-070X

Jurnal ABDIMAS Vol. 2,No.3, Agustus 2021,Hal(80-85)

@ Prodi Manajemen Fakultas Ekonomi Universitas Pamulang

Email: abdimasjurnal.unpam@ gmail.com Telp: (021) 741-2566 pembangunan umat islam maka untuk alasan-alasan tersebut Pelatihan Pembuatan Teh Sereh Dalam Memanfaatkan Waktu Luang Menambah Penghasilan Ibu Ibu Majelis Taklim Bintaro ini dilaksanakan. Pengembangan SDM tidaklah hanya terbatas pada tugas tertentu, tapi bertujuan untuk meningkatkan kepribadian dan sikap untuk pertumbuhan menyeluruh yang akan membantu mereka menghadapi tantangan di masa depan. Ini mengubah pola pikir ibu-ibu dan membuat mereka lebih menantang atau bersaing.

Solusi yang tepat untuk mengatasi permasalahan tersebut adalah dengan memberikan pelatihan yang perlu di lakukan secara berkelanjutan sehingga dapat memberikan mereka bekal dalam menghadapi persaingan dan melihat peluang di masa yang akan datang, di samping juga memberikan mereka pengetahuan berwirausaha yang mempunyai etika bisnis, menangani keluhan serta cara memasarkan produk yang baik. Mitra yang kami pilih untuk pelaksanaan Pelatihan Pembuatan Teh Sereh Dalam Memanfaatkan Waktu Luang Menambah Penghasilan Ibu Ibu Majelis Taklim Bintaro adalah ibu-ibu Majelis Taklim Bintaro. Hal ini terutama karena banyak warga yang terkena dampak dariPembatasan Sosial Berskala Besar yang diberlakukan di DKI Jakarta.

\section{Tujuan Pengabdian Kepada \\ Masyarakat}

Tujuan dari Pelatihan

Pembuatan Teh Sereh Dalam

Memanfaatkan Waktu Luang

Menambah Penghasilan Ibu Ibu

Majelis Taklim Bintaro yang kami lakukan untuk membantu memberikan pelatihan tentang pembuatan teh sereh, memfasilitasi alat dan bahan dalam pengembahan usaha pembuatan teh sereh, memberikan pelatihan tentang cara memanfaatkan waktu dengan baik sehingga ibu-ibu majelis taklim dapat menambah penghasilannya, memberikan pelatihan bagaimana memanfaatkan dunia digital dalam mengambangkan usaha ibu-ibu majelis taklim, dan membantu memberikan pelatihan kepada ibu-ibu majelis taklim terkait strategi dan jaringan pemasaran serta manajemen usaha yang baik dalam mengembangkan usahanya lebih lanjut.

\section{Manfaat Pengabdian Kepada Masyarakat}

Manfaat dari dilakukannya Pelatihan Pembuatan Teh Sereh Dalam Memanfaatkan Waktu Luang Menambah Penghasilan Ibu Ibu Majelis TaklimBintaro adalah untuk mengembangkan bakat dan keterampilan dari ibu-ibu majelis taklim, mempublikasikan teh sereh sebagai komoditas yang dapat memberikan penghasilan tambahan, meningkatkan kualitas SDM dari ibuibu majelis taklim, dan menciptakan UMKM baru di lingkungan setempat

\section{METODE \\ KEGIATAN}

PELAKSANAAN

Metode kegiatan Metode pendekatan untuk pelaksanaan kegiatan PKM pada masyarakat yang digunakan adalah melalui kunjungan langsung ke Mushola Al-Khosyiah Bintaro dengan melakukan diskusi dan memberikan seminar,. Metode yang digunakan pada kegiatan ini adalah menggunakan metode pelatihan dan pendampingan terhadap ibuibu majelis taklim di lingkungan tersebut dalam hal Pembuatan Teh Sereh Dalam Memanfaatkan Waktu Luang Menambah Penghasilan Ibu Ibu Majelis Taklim. Melalui kegiatan pelatihan ini diharapkan dapat memiliki usaha masing-masing yang dapat berjalan lancar dan sukses usahanya.

\section{HASIL DAN PEMBAHASAN}

Hasil dari pemberian materi kewirausahaan pembuatan danpengolahan sereh menjadi minuman siap saji yang bisa dijual apalagi dimasa pandemicini dimana masyarakat cenderung mencari bahan makanan atau minuman yang berfungsi meningkatkan daya tahan tubuh yang diberikan oleh dosen Manajemen 


\section{JURNAL ABDIMAS

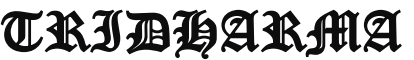

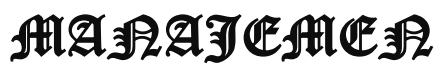

P-ISSN 2615-6849, E-ISSN 2716-070X

Jurnal ABDIMAS Vol. 2,No.3, Agustus 2021,Hal(80-85)

@ Prodi Manajemen Fakultas Ekonomi Universitas Pamulang

Email: abdimasjurnal.unpam@gmail.com Telp: (021) 741-2566
Universitas Pamulang beberapa ibu-ibu menjadi lebih termotivasi untuk dapat belajar berwirausaha dan memulai usaha dari rumah.

Selain pemberian materi dan motivasi, tim PKM juga mengadakan praktekcara pembuatan teh sereh yang bisa dijadikan modal ilmu untuk memulai usaha. selainitu, bersama tim dari dosendosen lain dilakukan juga learning by doing denganmengadakan simulasi cara dagang dan bahasa dalam menjual produk, dan cara mendisplay produk dengan benar untuk berjualan secara online.

Dari serangkaian kegiatan pengabdian Tim PKM Dosen dan mahasiswa Fakultas Ekonomi jurusan Manajemen Universitas Pamulang, maka hasil dari kegiatan pengabdian yang dilakukan adalah sebagai berikut:

1. Pelaksanaan dalam Pemberian motivasi dan ilmu kewirausahaan

Dalam Pemberian motivasi dan ilmu kewirausahaan kepada ibu-ibu jalan mawar 3 Rt. 004 di Pesanggrahan Bintaro ada beberapa pemateri dari dosen dan mahasiswa. Keilmuan wirausaha yang dijelaskan bukan hanya mengenai teori tapi juga praktek.

2. Mengadakan Praktek dan simulasi Cara Pembuatam Teh Sereh.

Dosen Unpam sebagai pihak penyelenggara mengadakan praktek dan simulasi cara mulai membuat teh sereh. Langkah-langkah dari pemotongan sereh, proses menjemur dan mengolah menjadi teh, praktek cara membuat kemasan dan praktek cara berjualan di media social.

3. Tim PKM Dosen Unpam memberikan Bimbingan dalam menjalankan usaha pembuatan dan penjualan the sereh hingga ibu ibu mampu berdiri sendiri dalam produksi dan promosi serta penjualan teh sereh.

4. Membuat Kartu atau form evaluasi bisnis untuk peserta PKM

Pihak Mitra yaitu ibu ibu di jalan mawar diberikan kartu atau form evaluasi bisnis sebagai tindak lanjut PKM agar mereka dapat mengetahui urutan dalam pembuatan teh sereh, membeli bahan baku, operasional usaha, menjual produk hingga mendapatkan laba serta memajukan usahanya sampai berkembang dan memperolehcabang usaha di beberapa daerah. Kartu evaluasi ini akan dikontrol oleh Tim PKM Dosen-dosen Manajemen Unpam secara berkala baik dalam memulai usaha, dalam seminggu sekali, sebulan sekali ataupun triwulan sekali. Hal ini dilakukan agar mereka dapat merasa aman dan terkendali dalam menjalankan usahanya hingga usahanya semakin berkembang pesat.

\section{KESIMPULAN DAN SARAN}

\section{Kesimpulan}

Pemberian Motivasi dan ilmu kewirausahaan yang diberikan oleh dosen-dosen Fakultas Ekonomi Universitas Pamulang dapat membuahkan hasil yang positif terlihat dari sikap yang ditunjukkan oleh ibu ibu jln Mawar Rt. 03 Pesanggrahan Bintaro, dalam penyuluhan ibu ibu sangat antusias mengikuti rangkaian kegiatan acara dari awal sampai akhir serta saat tanya jawab dan kuis, ibu ibu dengan semangatnya bertanya pada sesi tanya jawab dan menjawab kuiskuis yang diberikanoleh dosen-dosen Fakultas Ekonomi Universitas Pamulang. Pertanyaan yang diajukan oleh ibu ibu meliputi hal-hal terkait bagaimana menjadi memulai usaha teh sereh, bagaimana mengolah sereh jadi teh, bagaimana kemasan yang baik dan bagaimana menjual produk melalui media social.

\section{Saran}

Guna tercapai tujuan pengabdian yaitu mewujudkan ibu ibu yang produktif yang berbekal ilmu wirausaha yang kreatif, inovatif dan diferensiatif, ada beberapa saran yang perlu diperbaiki, yakni:

a. Bimbingan berkelanjutan kepada Tim PKM dosen agar usaha dapat terus konsisten berjalan dan menghasilkan laba yang 


\section{JURNAL ABDIMAS

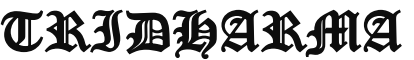

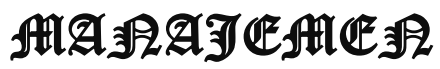

P-ISSN 2615-6849, E-ISSN 2716-070X

Jurnal ABDIMAS Vol. 2,No.3, Agustus 2021,Hal(80-85)

@Prodi Manajemen Fakultas Ekonomi Universitas Pamulang

Email: abdimasjurnal.unpam @ gmail.com Telp: (021) 741-2566 diharapkan

b. Evaluasi usaha secara berkala yaitu agar usaha yang dijalankan dapat diketahui mana yang belum maksimal dapat dijalankan agar usaha yangdijalankan mengalami peningkatan terus menerus. Diharapkan ibu ibu terus belajar dari pengalaman wirausaha yang sudah berhasil dalam berwirausaha.

c. Saran kami bagi ibu ibu Jl. MAwar 3 Pesanggrahan Bintaro untuk dapat memiliki usaha masing-masing yang dapat berjalan lancar dan sukses usahanya.

\section{UCAPAN TERIMAKASIH}

Ucapan terimakasih atas terlaksananya kegiatan pengabdian ini disampaikan kepada:

1. Universitas Pamulang.

2. Dekan Fakultas Ekonomi Universitas Pamulang.

3. Kepala Program Studi Manajemen yang telah memberikan persetujuan dan motivasi dalam terlaksananya kegiatan ini.

4. Ketua RT 004 RW 005 Bintaro Pesanggrahan Jakarta Selatan.

5. Rekan-rekan mahasiswa Univeristas Pamulang

Berbagai pihak yang membantu dalam terlaksananya kegiatan ini.

\section{DAFTAR PUSTAKA}

Dewan Redaksi Ensiklopedia Islam (Ed) Majelis. 1994. Ensiklopedia Islam. Ichtiar Baru Van Hoeve. Jakarta

Hanny, R., Nurhadi, A. N., Nurismalatri, N., Harsono, Y., \& Fitria, J. R. (2020). Pemberdayaan Usaha Kreatif dengan Manajemen Keuangan untuk Memaksimalkan Laba di Rumah Gemilang Indonesia Al Azhar, Sawangan Depok. DEDIKASI PKM, 1(1), 1-5.

Khayati, E. Z. (2008). Pendidikan dan Independensi
MUSAWA(61),

19-35. https://doi.org/16.14421/musawa/2008.6 $\underline{1.19-35}$

Munarsih, M., Hanny, R., Farida, S. I., Anggraini, N., Priyanto, H., \& Fauzi, A. (2021). Pembinaan Usaha Secara Online Untuk Meningkatkan Pemasaran Di Masa Pandemic Covid-19. Jurnal PADMA: Pengabdian Dharma Masyarakat, 1(1).

Nurita, E., Hanny, R., Anggraini, N., Amirudin, A., \& MT, R. B. (2020). PEMASARAN ONLINE SEBAGAI SOLUSI DALAM MENINGKATKAN KEUANGAN PENJUALAN DIMASA PANDEMIK PADA NELAYAN DI KELURAHAN PULAU PARI KECAMATAN KEPULAUAN SERIBU SELATAN. DEDIKASI PKM, 2(1), 113117

Pasaribu, V. L. D., Agrasadya, A., Shabrina, N., \& Krisnaldy, K. (2020). Menjadi Enterpreneur Muda Yang Memiliki Jiwa Leadership Untuk Menghadapi Masa Depan. Abdi Laksana: Jurnal Pengabdian Kepada Masyarakat, 1(1).

Pasaribu, V. L. D., Sulaiman, S., Sutiman, S., Thaharudin, T., \& Purnomo, B. Y. (2020). Pengenalan Letak Posyandu Terdekat Dikelurahan Pisangan Dengan Manajemen Pemasaran Revolusi 4.0 Untuk Meningkatkan Pengetahuan Masyarakat Letak Dan Fungsi Posyandu Terdekat Pada Kelurahan Pisangan. Dedikasi Pkm, l(1), 105-110.

Pasaribu, V. L. D., Jannah, M., Fazar, M., Putra, S. P., Monalisa, M., \& Sofa, M. (2021). MENINGKATKAN PRODUKTIVITAS USAHA DIMASA PANDEMI PADA IBU PKK RT 004/003 KELURAHAN SAWAH BARU CIPUTAT, TANGERANG SELATAN. Abdi Laksana: Jurnal Pengabdian Kepada Masyarakat, 2(2), 295-301. 


\section{JURNAL ABDIMAS

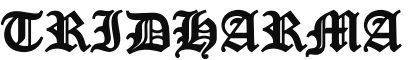

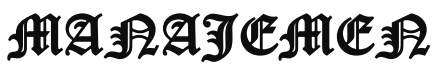

P-ISSN 2615-6849, E-ISSN 2716-070X

Jurnal ABDIMAS Vol. 2,No.3, Agustus 2021,Hal(80-85)

@ Prodi Manajemen Fakultas Ekonomi Universitas Pamulang

Email: abdimasjurnal.unpam @ gmail.com Telp: (021) 741-2566
Pasaribu, V. L. D., Yuniati, H. L., Pranata, R., Sembayu, R., Purba, S. M., \& Nurbayani, T. T. A. (2021). MANAJEMEN KEUANGAN UNTUK MENGHADAPI DAN BERTAHAN DI ERA COVID 19. Jurnal Abdimas Tri Dharma Manajemen, 2(2), 12-18.

Pasaribu, V. L. D., Dwiyatni, A., Sabina, C., Ridwan, M., Gunawan, D. D., \& Noviani, B. C. (2021). EVALUASI PENERAPAN 3M DIMASA PANDEMIC COVID 19. Jurnal Abdimas Tri Dharma Manajemen, 2(2), 54-60.

Priadi, A., Pasaribu, V. L. D., Virby, S., Sairin, S., \& Wardani, W. G. (2020). Penguatan Ekonomi Kreatif Berbasis Sumber Daya Desa Dikelurahan Rempoa. Abdi Laksana: Jurnal Pengabdian Kepada Masyarakat, 1(3), 356-35

Surahman, A., Fitria, J. R., Hanny, R., Rachmawan, A., \& Fadli, A. A. Y. (2021). HIPNOSIS, NLP DAN MOTIVASI

UNTUK MENINGKATKAN KUALITAS SDM GURU DI SEKOLAH BHAKTI PRIMA PAMULANG. Community Development Journal: Jurnal Pengabdian Masyarakat, 2(1), 81-83.

Surat Keputusan Gubernur daerah Khusus Jakarta Nomor 57 Tahun 2021 tentang perpanjangan pemberlakuan jangka waktu dan pembatasan aktivitas luar rumah pembatasan social skala besar

Tunggal, Amin Widjaja. 2012. Manajemen: Suatu Pengantar. Rineka Cipta. Jakarta

Wibowo. 2014. Manajemen Kinerja, ed.revisi. Rajawali Pers. Jakarta

https://hellosehat.com/nutrisi/tips-makansehat/cara-membuat-teh-serai/?amp=1 https://m.republika.co.id/berita/llj783/resepmembuat-teh-sereh

https://www.kompas.com/sains/read/2021/05/1 2/203000423/6-manfaat-sereh-salah- satunya-mampu-turunkan-

$\underline{\text { kolesterol?page }=\text { all }}$

\section{DOKUMENTASI KEGIATAN}
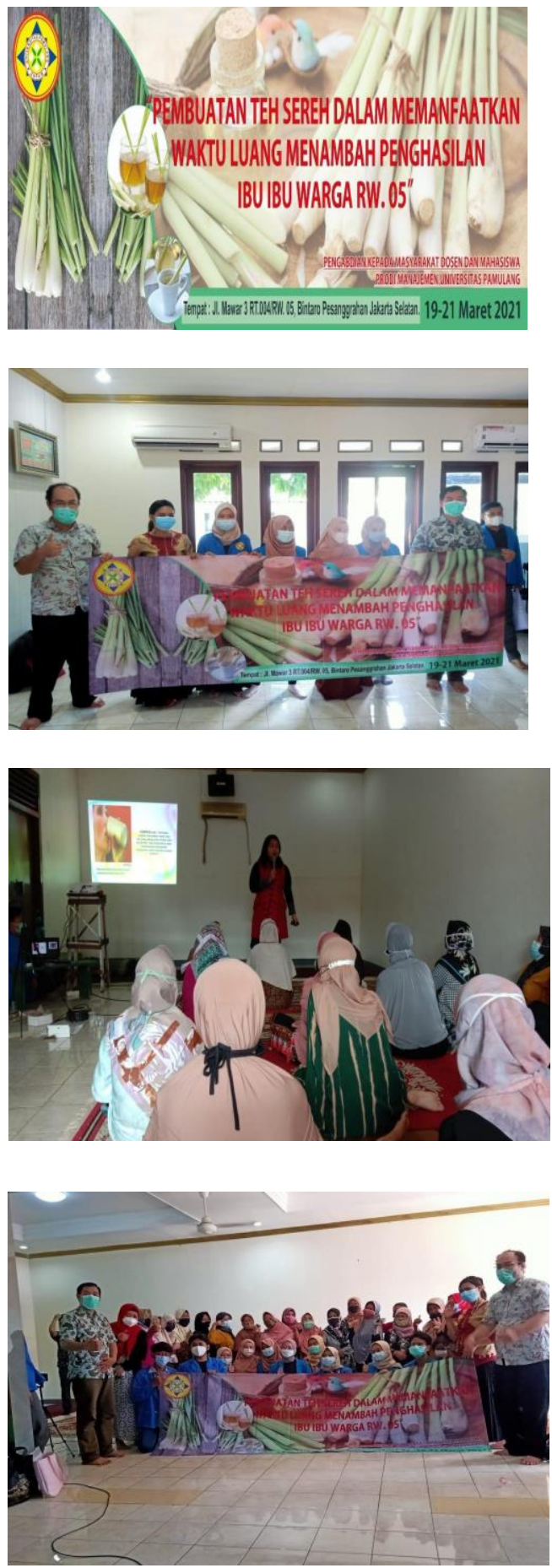
JURNAL ABDIMAS

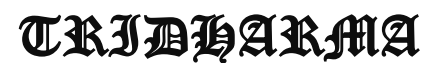

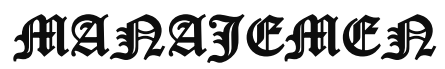

\section{P-ISSN 2615-6849, E-ISSN 2716-070X}

Jurnal ABDIMAS Vol. 2,No.3, Agustus 2021,Hal(80-85)

@ Prodi Manajemen Fakultas Ekonomi Universitas Pamulang

Email: abdimasjurnal.unpam @ gmail.com Telp: (021) 741-2566 